\title{
Getting texts to talk. A critical analysis of attempts at eliciting contemporary messages from ancient holy books as exercises in religious communication ${ }^{1}$
}

NGTT DEEL 55, NO 1, 2014

\section{Lombaard, CJS}

Christian Spirituality,

University of South Africa

\section{ABSTRACT}

Religious Communication as academic discipline analyses the ways in which the spiritual commitments of humanity find expression in and through communicative acts. Diverse and multi-disciplinary as this discipline is, one of the aspects Religious Communication studies, is the problematic religiously inclined people experience in eliciting a meaningful message, relevant to modern times, from holy texts (such as the Bible) that stem from ancient times, dissimilar cultures, and far-removed communicative contexts. Within Christianity such problematic have, inter alia, given rise in the modern era to exegesis as an expert enterprise with which to practice the science and art of both understanding the texts within their ancient contexts and eliciting valid messages from them for current times. In such endeavours, Communication and Theology mix in a unique way as an expression of Religious Communication. In this contribution, the author builds forth on previous publications in the fields of Religious Communication and of Exegesis, to discuss here some major modern attempts in this regard. The pre-modern allegorical use of biblical texts were through the rise of historical consciousness, as part of the Enlightenment, replaced by historical-critical interpretations of the holy texts, which then dominated the exegetical scene for about two centuries. During the past half-century, however, different a-historical methods have been developed. In this contribution, the communicative intent with each of these exegetical methodologies are described and compared critically.

1 Paper read at the $11^{\text {th }}$ Annual International Conference on Communication and Mass Media (Athens Institute for Education and Research), 13-16 May 2013, Athens, Greece. 


\section{GENERAL CROSS-DISCIPLINARY ORIENTATION: THE IMPOSSIBLE AND THE POSSIBLE OF “GOD TALK” IN OUR TIME}

Talk of God, the domain of Theology, has in Western cultural streams of the past two millennia always found itself between the dual poles of the impossibility of speaking of God and the impossibility of not speaking of God. The latter has been acknowledged in refined theological reflection as being a function of the category of revelation (cf. Berkhof 2007:43-115) as divine self-disclosure to humanity, without which all talk of God would, for religiously inclined people, become speculative. This insight is, to be sure, itself a confession of faith, namely of the kind that constitutes a tipping point between Theology and the approach of the Humanities or Social Sciences, that is, within the broadly accepted scholarly protocols of the Humanities in which such a confession is impossible to employ ${ }^{2}$. Within the Humanities, "God talk" (a now popular expression, seen in the work of Allen 2002 and others) does not require a sense, a confession or a spiritual orientation on the existence of God (and all the implications that that would imply) or not - although the implicit inclination is towards the latter. The Humanities do not consider God. Religious humanity, the psychological and social effects of religiosity and the philosophical implications around ideas about divinity however all do lie within the ambit of such non-theological intellectual consideration and social-scientific investigation. No kind of religious orientation is required when godliness is considered scientifically within the Humanities.

Of course, the way in which the Humanities consider religiosity or spirituality is not without its own general orientations, which do colour in various ways what is "seen" (studied / considered) and what is not. That is a phenomenon inherent to all intellectual inquiry. This has in broad terms been demonstrated by the philosophy of science, with Thomas Kuhn's work (1962) on paradigms of understanding as the most influential work in this regard.

2 Religiously confessional Humanities scholarship is of course possible - cf. e.g. Bratt \& Wells 2001. Although I would hold (on the grounds indicated in Lombaard \& Froneman 2006:151-158) such e.g. "Christian scholarship" to be intellectually viable and legitimate, even commendable in the extent that that its proponents spell out at least some of their underlying assumptions more clearly than is often the case in the Humanities, or other broad fields of scholarship, I find myself more at home with the more generally-accepted non-/a-religious models of Humanities scholarship, because of the often more daring, more open and more critical atmosphere of intellectual engagement one encounters in such spheres. 
When these two approaches of Theology and the Humanities meet, much creativity can be found ${ }^{3}$. To limit ourselves within the Humanities to the specific field of Communications, ample examples are to be found of attempts at disciplinary intersection with Theology. These include three broad approaches:

- From one side, to attempt to produce theologies of (aspects of) communication (cf. e.g. Mugridge \& Gannon 2008);

- From the other side, to come to communicative insights on (aspects of) theology (cf. e.g. Attfield 2001); and

- In amalgamation: to combine these two disciplines formally within the scholarly field of Religious Communication (cf. Lombaard 2006:141-150, Lombaard \& Froneman 2006:151-158 for an overview).

In this contribution, a very small section of this broad intersection (cf. Du Toit 1992:178-192) is taken into consideration. The intended new contribution made here is namely to explore from the side of Communication Science the communicative intent of one relatively small but highly influential aspect of the theological enterprise, namely exegesis - the methodologically refined exploration of the meaning of biblical texts (for other definitions of exegesis, cf. i.a. Brown 2007:23-26, Porter \& Clarke 1997:4-21). This is done here with the purpose to form an orientation from which to evaluate other, broader-scale projects at eliciting messages from ancient Scriptures, namely Scriptural Reasoning ${ }^{4}$, Biblical Reasoning ${ }^{5}$ and Textual Reasoning ${ }^{6}$, as part of an on-going research trajectory on evaluating the way in which the Bible is employed within latter-day expressions of spirituality (cf. e.g. Lombaard 2008a:263283 / 2012a:139-169; for a broader exposition of the underlying model of Biblical Spirituality at work here, cf. Lombaard 2008b:139-153 / 2012a:111-137; 2012b:933934).

3 The inherent tensions should not be forgotten, though. Combining disciplines or interpreting and evaluating the one from the perspective of the other hold many problems of misunderstanding. The distinct scholarly protocols in different academic disciplines, the at times different world views from which are foundationally departed, and the false confidence created by specialisation in one discipline that the other could easily be mastered with equal depth and nuance, are just three examples of this.

4 Cf. http://etext.lib.virginia.edu/journals/ssr, www.scripturalreasoning.com, www.scripturalreasoning.org.

5 Cf. http://biblerevival.com/blog/tag/biblical-reasoning; Webster 2008:733-751.

6 Cf. www.bu.edu/mzank/STR/general.html, http://etext.lib.virginia.edu/journals/tr/, Ochs \& Levene 2002. 
Within deliberations on exegesis, Communication Theory has indeed been employed (e.g. Brown 2007). However, this most often does not go beyond the most basic of communication models - the linear "Sender - Message - Receiver" schema (cf. e.g. Narula 2006:16), which is intellectually more indebted to Aristotle (cf. Narula 2006:25) than to modern Communications Theory ${ }^{7}$. In an interesting intra-disciplinary development within Exegesis, this model has come to be used not only to portray the process of communication of an ancient text in its context, but also to summarise briefly the history of modern exegesis, thus entrenching this basic model's use within the discipline. Earlier exegetical enterprises that sought to retrieve meaning from within the mind of the ancient author, are namely presented as Sender-oriented, whereas text-analytical exegesis was regarded as Messagefocussed, and reception history / reader response oriented interpretations were presented as the most candid, acknowledging as they do that the Receiver, the modern reader of the text, in reality determines its meaning (Lategan 1984; cf. Van der Merwe 1995:47-51). However, to end the use of Communication Theory there is to leave the cross-disciplinary interaction, as it relates to exegesis, underexplored ${ }^{8}$. Therefore, in order to use this most basic of Communication models in a slightly more complex, more nuanced way, the focus here will be on communicative intent.

The latter will be undertaken below with respect to exegetical methodology. Over the centuries, an array of exegetical methods have namely emerged, each dominant within a certain era and social circle. Below, each of the methodologies is briefly described, and then an analysis is offered: what is it about the ancient text that the methodology seeks to communicate? Exegesis, namely, cannot tell us everything about a text: the methodology followed, and at times purposely chosen, inadvertently opens the exegete's eyes to certain aspects of the text under investigation, yet at the same time blinds the exegete to other aspects of that same text (cf. Lombaard 2013). Only certain aspects of the dynamics of an ancient biblical text can be conveyed by an exegetical study. As with modern Bible translations, "elke vertaling is'n vertelling" (Lombaard 2002:754-765) - each translation is a narration. Similarly, with exegesis: each attempt at conveying the meaning of an ancient text tells a story, namely of

7 On the complexity of modern Communication Theories, cf. Craig 1999:119-161 / 2007:63-98.

8 Not surprisingly, in e.g. the Missiology and related sections of the encyclopaedia of theological disciplines, Communication Theory comes into play differently, e.g. with respect to the Mass Media (e.g. Schultze 2000) and Intercultural Communications (e.g. Segami 2008). Vanhoozer in his 1998 and other works combines Communication Theory with an explicit seeking of theological meaning - a project that deserves an analytical-evaluative study of its own. 
certain aspects of the ancient text under consideration. Not everything can be said of a classic text (and this is true of all good texts in the "Western canon" of Bloom 1994). Below, then, what an exegetical method can say, the communicative intent of that method, is explored.

\section{THE “US / THEN" DIVIDE OF EXEGESIS}

The history of exegetical methodology (cf. e.g. Sæbø 1996; Kraus 1982; thematically: Soulen \& Soulen 2001) is for the main part testimony to the difficulty of coming to terms with classic texts held to have religious authority. These are therefore, in that sense (thus leaving aside here the difficulties associated with inspiration theories, ideas on inerrancy, and the like), holy texts, in which a living deity is believed to have addressed people in the past, and with which the deity continues to do so with the faithful, throughout the centuries, up to this day.

The single most pivotal element that divides exegetical methods into two groups, is the importance accorded history. Since before the identification by Lessing (1979 [1777]:13) of "der garstig breite Graben" between the ancient world/s in which the text originated and the modern world/s of the interpreters, history has become a kind of Midas touch (Otto 2004:14) for exegetes. Once the eyes are opened to the importance of history (cf. Le Roux 1993:35-63) - that is, inter alia: that the ancient setting (Sitz im Leben, as the term popularised by Gunkel 1913:33) is key to come to the fullest possible understanding of the text - it becomes difficult to look at the biblical texts differently. However, both prior to the advent of historical-critical exegetical methods, and again since the 1970s with the scholarly search for nonor a-historical interpretative methods, history was not the primary framework for understanding the Bible. Rather, with the older allegorical interpretations of the Bible texts and again, in different ways, with the newer text-immanent readings (i.e. narratological, structuralist, semiotic, genitive-theological ${ }^{9}$, socio-scientific and, most recently, mystagogical approaches) of prime importance is the meaning for me or us.

This distinction around history and meaning becomes something of a loose organising principle below: it will be clear that what the exegetical method seeks to communicate about the ancient text lies always on one side or the other of this "us / then" (or "me / then") divide. To be clear, the recurring criticism of the historicalcritical methods of exegesis, that it destroys meaning for the present, is based on misconceptions, on the "politics" of interpretation between church and academia, on the complexities of the task of understanding (hermeneutics), and at times, simply

9 I understand under this category also the reader-response kind of theories. 
on intellectual laziness. On the other hand, the claim of the alternative, a- or nonhistorical methods that they would render more clearly meaning for the present is itself misplaced (cf. Lombaard 2008c:49-62). The matter is thus more complex than a naïve either-or set of alternatives would imply. However, these complexities are for the moment set aside, in order to come to grips with the task at hand: to indicate what the communicative intent is with these methods.

\section{THE COMMUNICATIVE INTENT OF EXEGETICAL METHODS}

Five representative exegetical approaches will in this section be briefly described, with the communicative intent of each approach then indicated. These methodologies are:

- allegory;

- historical-critical methodologies;

- text-immanent methodologies;

- genitive-theological hermeneutics;

- mystagogical appropriation.

Naturally, more exegetical approaches are to be found, and most of these approaches consist of a variety of methodologies, closer or loosely related. However, by concentrating on just these five, the most important sense of the argument here will have been conveyed.

\subsection{Making (taking) meaning for me 1: Pre-modern allegory of biblical texts}

The allegorical way of making meaning from the biblical text, the more popular of the two ancient ways of interpretation over against the more literal Antiochene school of reading the Bible ${ }^{10}$, was couched in a series of interpretative moves that came down to "more imposition than exposition" of meaning (Richardson 2007:14; cf. Zuck 1984:37). The truest meaning of a text was regarded to lie behind the words, rather than in the words, so that the words are mere signs or symbols of deeper, holier meaning. It is in the latter that the divine can be heard. The divine thus speaks in a kind of mystic oracle, which requires deciphering in order to find the meaning God intended for the time of the interpreter. Not without continued influence, developments from this early impetus include the later "fourfold sense" of Scripture and some modern charismatic Bible interpretations. It is also precisely

10 Behind this lies the Platonic-Aristotelian divide on either an idealist or a realist worldview. 
this way of understanding the Bible that lies behind literary sensations in our time such as the novel The Da Vinci Code (Brown 2003; cf. Lombaard 2009:285-298; in lighter vein, cf. Eaton 2006 \& Kombuis 2003), and is clearly present in the millennial expectations when especially the New Testament book of Revelations is read as if it secretly "predicts" important events in our time, such as immanent cataclysm, the end of the world, or such outcomes of salvation history (cf. Vojtíšek et al. 2013).

Though the "true" meaning accorded a text, or even just a word, can be wildly speculative, there is always a controlling background, namely in the theological framework of the interpreter. However, the understanding is that the biblical text conveys these insights, rather than that they are imposed, with the text interpreter's context taking primacy over the ancient context/s in which the text came into existence.

The communicative intent of this form of exegesis is thus to unearth the "true" meaning, what God seeks to convey, but which is couched in symbolic mystery within the holy text. It is, in this understanding, only through enlightenment that this meaning can be obtained from the text. Such enlightenment comes from on high. In a strangely circular way of thinking, never acknowledged, it is therefore God who unveils the meaning of the holy text that God had self hidden there. Though the message from God is present in the text, it is not easy to detect; special, holy guidance is required. Only in this way it is the word of God to be had from the Word of God. The implicit communicative intent of scriptural interpretation is thus to hear the holy will for the people. These people are however not the ancient audience/s intended by the original author, but the latter-day reader/s of the text or the audience addressed by the practician of allegoric exegesis. The us of the addressed group, the me of the interpreter of the identified texts read allegorically, are the primary role players in this communicative process.

\subsection{Mining meaning for the modern(ist) mind: Historical-critical exegetical methods}

Though often maligned by an older generation of confessionally inclined theologians, the historical-critical methodologies of reading the Bible has been acknowledged in more recent years as having indeed had both apologetic intentions and continued confessional value (cf. e.g. Fitzmyer 2008). This was namely a set of methods developed in order to deal with the rise in historical consciousness that went along with the Enlightenment. This set includes, as just the most prominent exegetical approaches: 
- Textual criticism, in which an agreed-upon standard text (or text tradition) of either the Old or New Testaments are restored, as far as it would be conceivable, to as close as possible to an original form (cf. e.g. Deist 1988 \& Petzer 1990);

- Literary criticism, in which the different identifiable texts within the Bible were isolated, as far as possible, and put into their historical relations to one another (the name of Wellhausen is always mentioned in this regard; cf. e.g. Wellhausen 1876);

- Form criticism, in which the genre identification of the texts are refined and related as closely as possible to (at times certainly hypothetical) real-life situations in which the texts forms could either have originated or had been used in antiquity (Gunkel, as the originator of this form of exegesis - cf. e.g. Gunkel 1925 - has been influential in other intellectual disciplines too);

- Redaction criticism, in which the editing activities on ancient discrete texts are retraced as far as possible (cf. Perrin 1969);

- Tradition criticism, in which the intra-textual interpretative histories are retraced as far as possible (with Von Rad as the father of this approach; cf. e.g. Von Rad 1960).

Already this brief summary of the historical-critical methodologies reveals that they were primarily concerned with determining the text in its most ancient form as it had functioned it its most ancient setting/s, and from there wanted to trace how the textual interpretation history developed. Not intended to destabilise faith, but rather in an implied sense to rescue it for the intelligentsia of the time, these methods repeatedly had that destabilising effect, though, because the scholarly findings subverted often dearly held positions which now could be proven to be invalid or historically contrived or, at the very least, historically determined. The early positivist underpinnings of the findings, or of the debates around them, further strengthened these negative perceptions. However, the communicative intent of these methodologies was to seek a "purer" form of the text, cleansed of interpretative layers from post-canonical church history and popular conceptions, and thus to understand the faith traditions in their most unadulterated forms. In time, many of the assumed positivist underpinnings had been let go of, as exegetes realised that the later interpretations, within texts themselves, between texts, and by later interpreters, were as much historically situated and understandable as were the earlier sources of these interpretations. That included the own understandings. Thus, the communicative intent of these methodologies have been modified in a 
sense to show the interrelationship between history and text and interpretation, from the earliest traceable form of the text up to the modern interpreters' views.

\subsection{The text tells all: Text-immanent methodologies}

Yet, many scholars did not see matters in the way just explained. For them, a new method had to be adopted in order to come to more faith-full understandings of the Bible texts. Thus, new methods had been adopted by groups of exegetes, which look at the texts as texts rather than in their relation to their history. Here, composition not in its sense of coming into being is studied; rather the composition of the a-historical building blocks of the text is considered.

The two most important strands of this broad text-immanent approach are:

- Structuralism (at times also called discourse analysis, and related to semiotics - cf. Patte 1990), which seeks to understand interrelationships of the parts of a text (most often words), not to the historical world "outside" of any given text, but to the other parts of the text. This method found its roots in early 20th century Russian formalism, via an understanding of De Saussure's 1922-work. However, typical of this method, its own historical roots are not very well studied by exegetes. More important is what it reacts against, and what it wishes to present: stability of meaning, structurally indicated. Within this broad aura of understanding, a number of loosely relatable forms of structuralism had developed (cf. e.g. Richter 1971 \& Prinsloo 1988);

- Narrative exegesis, which wants to understand the storyline or plot and all other literary aspects of the text, in order to come to terms with how the telling of the account unfolds intrinsically and artistically (cf. e.g. Tolmie 1999). In the telling of the story, truth resides, and it is this manner of conveying meaning, by retelling, that the account being retold lives again for the modern reader / hearer. By analysing a text narratologically, the inherent value of the text itself comes to the fore.

The communicative intent of this broad exegetical approach is to find meaning in the text, the whole text, and nothing but the text. In the text, stability of meaning exists, and the text-immanent method employed will extract it. About this the proponents are confident. Whereas the historical-critical methodologies are experienced as not relating meaning for today, because of them delivering inconclusive and oftencontradictory results, they are habitually by proponents of text-immanent methods declared defunct. In the text-bound method the madness of meaning is tamed. The text has meaning, and the task of this exegetical method is to relay it. 


\subsection{Justice in our time: Genitive-theological exegetical methodologies}

When theologians use the term "hermeneutics", at least three broad forms of interpretative exercise can be implied: the philosophical branch, in which the understanding of understanding is explored (e.g. Gadamer 1975), the methodological strand, in which exegetical method is considered, and what has been called the genitive-theological exercise, in which modern socio-political corrective measures are strongly called for. In the latter, a cause of justice to which the interpreter is committed is taken as the prime interpretative criterion. This includes causes such as political freedom in theologies of liberation, or gender equality in theologies of feminism, or the ecology in theologies of the environment (cf. e.g. Segovia 2003). In all cases, though not always with this terminology, readings "against the grain" are undertaken. This "grain" against which a reading is undertaken usually refers to three matters, although it is seldom indicated in this way (since the description here is ideal-typical): the dominant understandings within the biblical text (e.g. on the social position of women), the ways in which these texts have been employed throughout history in church and wider circles (e.g. to serve an unjust cause), and an untenable socio-political state of affairs in the world at present.

Although the latter form of hermeneutics clearly draws heavily on the former two, its practitioners are most often too committed to the present cause to spend much time on philosophical and methodological considerations: the cause of justice at hand is too pressing to allow for too much valuable energy to be expended on anything that does not contribute directly to the rectifying the injustice/s. Historical analyses are often included, namely of how the biblical texts had been ab/used throughout history in order to give sanction to discriminatory or unsustainable practices (the issue of slavery is a classic case in point here), and also of the practices themselves, namely how they had come into being and had been kept in place. By such "unmasking" strategies that expose both the present intolerable situation and the suppressive interpretation histories, it becomes possible to suggest new ways of seeing the world and being in it. New, "liberative" interpretations of existing texts are proposed, and / or (aspects of) texts that have seldom in the past been given prominence are "foregrounded", and / or the inability of the ancient texts at all to deal with the modern issue is pointed out (e.g. Germond \& De Gruchy 1997). By proposing a new understanding, or, though rarely, quite an altered basic view of the religion concerned (e.g. Johnson 1992), the cause at hand is better served.

Although the agenda of the interpreters and hence also the new interpretations offered are often radical, for the most part the broad outlines of the Christian metanarrative (to employ here the language of Lyotard 1979) are kept to. Even in the rare instances where a rewritten Bible is proposed to favour the present cause, this is 
seldom meant as literally as Banana (1993:17-32) did, but is most often a metaphor for suggesting new readings.

The communicative intent of genitive-theological exegetical enterprises is different than any of the other methodologies discussed here. Socio-political change is namely called for directly, not only by implication, as may be the case with the other methodologies discussed here. Not conversion in the usual religious sense is called for, which then has implications for practice, but the practice itself is directly addressed here. This is an activist approach. Often, the directive impulse or foundational value of understanding is extra-biblical, for the common-sense reasons that these modern concerns are not found within the biblical texts, at least not in a way that makes easy sense within the prevailing values of our time, and / or the texts have been used precisely in favour of the other, now unmasked and hence discredited, oppressive side. The purpose of exegesis, or in a vague sense then: eisegesis, is to present the Bible, the faith and the situation in the modern world anew, so that a more just, equitable society may be the result. Idealistic as this approach is, it is therefore not unnatural that a "higher", what has earlier in this paragraph been called an extrabiblical benchmark of understanding / interpretation is employed. From this, the Bible is read inductively. Then, new "voices" (or messages) within / from the Bible are found, at times with far-reaching influence, as with the case of Latin-American liberation theology. Therefore, even though the initial point of departure may not have been deductive, from the Bible itself, it is most often the case that in the argumentation it is pointed out that the Bible has, after all, lesser-known texts or now better-understood texts that validate, for the religiously inclined at least, the theological validity of the favoured cause. Thus, new "empowering" readings of the texts, that is: in favour of the previously marginalised cause, now become possible. The Bible - and hence by implication: the church, the faith, or even God - has in this way been afforded a voice of restored respectability.

Though some elements of apologetics may be seen in this, this is seldom a directly visible intent of these exegetical methodologies. The approach here is more instrumentalist: to correct a current wrong, with the Bible regarded as an acknowledged potentially powerful force to the good, even though it may well in the past have been employed (or perhaps even, deployed, like a dangerous weapon) negatively with respect to the present cause.

\subsection{Making (taking) meaning for me 2: Post-modern mystagogy and biblical texts}

Mystagogy has in recent theological writings received renewed interest, particularly through the work done at the Titus Brandsma Institute, Radboud University, 
Nijmegen, the Netherlands (cf. however e.g. Dericquebourg 2001:149-158 \& Regan 1993:416-422). In the background of this renewed interest lies, implicitly, a dissatisfaction that scholarly exegesis of the biblical texts are not rendering results in which modern readers feel themselves addressed. However, unlike the newer text-immanent exegetical methods that have from the 1970s onwards been seeking meaning from method, here the express interest is to garner a divine encounter from the biblical text. As always in the history of Christianity when this term had been used, mystagogy is therefore still about "Christian initiation" (Reilly 1974; cf. Waaijman 2002:870-874). This, not in the sense of theological education or ministerial formation (although not unrelated to such aspects), but more: a personal, existential encounter is sought. Fully informed about the via negativa as a more sustainable way of discerning faith than the strongly dominant cataphatic theology in many Western(ised) societies, and thus fitting well with the sociologically newlyunfolding post-secularist cultural climate of our time (cf. Gorski et al. 2012, Nynäs et al. 2012; Lombaard 2012/2014), this is a more humble, less self-assured approach to finding meaning with the text. Important, therefore, is still that the text interacts with the hearer of today. In this interaction, in some way, an encounter with the holy is the corollary. Though finding meaning may be the goal, not finding meaning is an equally acceptable result too. Here, mystery is the principal sphere of orientation. This, though, is not a naïve engagement with the text, but finds itself in/formed by the intellectual history from the Enlightenment onwards. At the same time, though, it finds itself equally fully in/formed by the faith history of, though primarily Christianity, also Judaism, Islam and other faith traditions of the world.

The communicative intent here is thus not in the first instance to find the meaning of a biblical text, nor primarily to experience meaning for me, respectively us. Rather, an encounter is intended (cf. as a recent practical example Waaijman 2011:1-20). Meaning is negotiated - with the self, with the divine, via the text: "an experience that is already there is interpreted" (Waaijman 2002:870). Meaning - "clarification" (Waaijman 2002:872-873) - is sought, but if not found, the encounter is still regarded as valid; not fruitless. Meaninglessness is not meaningless. This is the mode of the mystic. Experience, grounded in the histories of faith and intellect and culture and the self, is meaning; therein God communicates. This is the mode of mystagogy.

\section{THE VALUE OF ANALYSING EXEGETICAL METHODS AS RELIGIOUS COMMUNICATION}

Religious Communication as an academic discipline examines the ways in which the spiritual commitments of humanity find expression in and through communicative acts. Diverse and multi-disciplinary as this discipline is, one of the aspects Religious 
Communication studies, is the problematic religiously inclined people experience in eliciting a meaningful message, relevant to modern times, from holy texts (such as the Bible) that stem from ancient times, dissimilar cultures, and far-removed communicative contexts. Within Christianity such problematic have, inter alia, given rise in the modern era to exegesis as an expert enterprise with which to practice the science and art of both understanding the texts within their ancient contexts and eliciting valid messages from them for current times. In such endeavours, Communication and Theology mix in a unique way as an expression of Religious Communication.

In this contribution, some major modern attempts in this regard have been briefly discussed. The pre-modern allegorical use of biblical texts were through the rise of historical consciousness, as part of the Enlightenment, replaced by historical-critical interpretations of the holy texts, which then dominated the exegetical scene for about two centuries. During the past half-century, however, different a-historical methods have been developed. In this contribution, the communicative intent with each of a representative selection of these exegetical methodologies has been described. The communicative intent for each of the respective approaches namely is:

- For the allegorical method, to find the "true" meaning God intends in the Bible, but which is hidden by means of symbolism or mystery. The intent of the "exegete" is to perceive this meaning through guided revelation. The Divine, which hid the meaning in the text, reveals the meaning from the text. In so doing, the holy will is discerned by the exegete and conveyed to the intended audience;

- For the historical-critical methodologies, no secret "code" within the text must be unveiled, but the mists of history must be pierced, in order to come to an understanding of the meaning of the texts. The intent of exegesis is to recapture and retrace, also to relive, the ancient meaning/s of the text-in-context. In that way, the meaning for today can be validly conveyed, where possible;

- With the text-immanent approaches, the communicative intent is again to find meaning within the text, but now not hidden, as with allegory, or terminally uncapturable, as in history. The texts themselves provide certainty of a firm meaning, and methodological exactness relays this certitude to today. Only then can the modern reader be well served by exegetes;

- In genitive-theological exegesis, the communicative intent is to create greater justice in the modern world by recouping lost meanings from within the biblical text. Change must happen, not solely within us humans, but especially in our world. The Bible, the history of its interpretation and modern society 
must be reread, understood anew, for this to happen. Then the Bible becomes a positively empowering resource towards a better world.

- In mystagogical use of the Bible, the communicative intent is a different kind of transformation, namely engagement with the text in order to re-evaluate and deepen the experience with the Divine. All the above is accounted for, but then more is required: also the direct sense of God, of the self and of the world is sought - an encounter goes beyond easy answers.

In the (acknowledged oversimplified) triangular relationship of God-personScripture experienced by most believers ${ }^{11}$, there are a number of well-established ways of participating in this triad of meaning. Only some of the major established exegetical / interpretative ways have been taken into review here. The diversity that we find as one of the characteristics in the biblical texts themselves (Lombaard 2011a:4965 ), we see reflected also in the diversity of exegetical approaches available, and points in some respects already to the diversity of religious commitments within our world (Page 2012:137-154). In all cases, there is an imbued sense within these broad approaches of the importance of "transhistorical intentions" (Hirsch 1994:549-567; cf. Brown 2007:116) with the biblical texts; however, the implied contestation on how best to elicit these intentions are clear from just the five approaches outlined above.

Precisely where this should all lead to, only unfolding history will tell us; certainly no "methodological imperialism" (Du Toit 2004:212) in which one approach completely rules out the others can be foreseen. The value of however pointing out the different things that these approaches want to do - their communicative intent is that this unfolding history can be more open and honest, and more susceptible to intellectual scrutiny.

\section{BIBLIOGRAPHY}

Allen, J T 2002. A Theology of God-talk. The language of the heart. Binghamton, NY: The Haworth Pastoral Press.

Attfield, D G 2001. Proclaiming the Gospel in a secular age. A general theory of religious communication. Aldershot, England: Ashgate.

11 This relationship was graphically represented in e.g. Lombaard 2011b:3 and further applied in e.g. Van der Merwe 2012:182. 
Banana, C S 1993. The case for a new Bible, in Mukonyora, I, Cox, JL \& Verstraelen, FJ (eds.) "Rewriting" the Bible: the real issues. Gweru, Zimbabwe: Mambo Press, 17-32.

Berkhof, H 2007. Christelijk geloof (negende, ongewijzigde druk). Kampen: Uitgeverij Kok.

Bloom, H 1994. The Western canon. The books and school of the ages. London: Papermac.

Bratt, J D \& Wells, R A 2001. The best of The Reformed Journal. Grand Rapids: William B. Eerdmans Publishing Co.

Brown, D 2003. The Da Vinci code. London: Corgi Books.

Brown, J K 2007. Scripture as communication: introducing biblical hermeneutics. Grand Rapids: Baker Academic.

Craig, R T 2007. Communication theory as a field, in Craig, RT \& Muller, HL (eds) Theorizing communication: readings across traditions. Thousand Oaks, CA: Sage Publications, 63-98.

Craig, R T 1999. Communication theory as a field. Communication Theory 9/2, 119-161.

Deist, F E 1988. Witnesses to the Old Testament (The Literature of the Old Testament, 5). Pretoria: NG Kerkboekhandel.

Dericquebourg, R 2001. Mystagogie et religions de guérison: Max Weber Revisté. Archives de sciences sociales des religions 46/113, 149-158.

De Saussure, F 1922 Cours de linguistique générale. (2e ed.) Paris : Payot.

Du Toit, A B 2004. Het diskoersanalise 'n toekoms? Hervormde Teologiese Studies $60 / 1 \& 2,207-220$.

Du Toit, D A 1992. Godsdiens en kommunikasie. Tydskrif vir Geesteswetenskappe 32(3), 178-192.

Eaton, T 2006. The De Villiers code. Cape Town: Penguin Books South Africa. 
Fitzmyer, J A 2008. The interpretation of Scripture. In defense of the historicalcritical method. Mahwah, New Jersey: Paulist Press.

Gadamer, H G 1975. Wahrheit und Methode: Grundzuge einer philosophischen Hermeneutik. Tubingen: Mohr.

Germond, P \& de Gruchy, S 1997. Aliens in the household of God. Homosexuality and Christian faith in South Africa. Cape Town: David Philip.

Gorski, P S, Kim, D K, Torpey, J \& Van Antwerpen, J (eds.) 2012. The post-secular question. Religion in contemporary society. New York: Social Science Research Council \& New York University Press.

Gunkel, H 1925. Die Psalmen, übersetzt und erklärt. Göttingen: Vandenhoeck \& Ruprecht.

--- 1913. Reden und Aufsatze. Göttingen: Vandenhoeck \& Ruprecht.

Hirsch, E D 1994. Transhistorical intentions and the persistence of allegory. New Literary History 25/3, 549-567.

Johnson, E A 1992. She who is. The mystery of God in a feminist theological discourse. New York: Crossroad.

Kombuis, K 2003. The secret diary of God (aged 91/2 million trillion years). Cape Town: Zebra Press.

Kraus, H-J 1982. Geschichte der historisch-kritischen Erforschung des Alten Testaments (3., erw. Auflage). Neukirchen-Vluyn: Neukirchener Verlag.

Kuhn, T S 1962. The structure of scientific revolutions. Chicago: University of Chicago Press.

Lategan, B C 1984. Current issues in the hermeneutical debate. Neotestamentica 18, $1-17$.

Le Roux, J 1993. The nature of historical understanding (or: hermeneutics and history). Studia Historiae Ecclesiasticae XIX/1, 35-63.

Lessing, G E 1777. Über den Beweis des Geistes und der Kraft, in Göpfert, HG (Hrsg.), 1979. Werke, 8. Bd.: Theologiekritische Schriften III, Philosophische Schriften. München: Hanser Verlag, 9-14. 
Lombaard, C 2013. Issues in / with Genesis 22: an overview on one of the most problematic biblical chapters. Verbum et Ecclesia 2013 (special edition for JH le Roux), forthcoming.

--- 2012a. The Old Testament and Christian Spirituality. Theoretical and practical essays from a South African perspective (International Voices in Biblical Studies 2). Atlanta, Georgia: Society of Biblical Literature.

--- 2012b. Om die Skrif tot stilte te bring... Gewaarwordinge oor Afrikaanse Bybelse spiritualiteit. Litnet Akademies (Godsdienswetenskappe) 9/3, 929-951 / http://litnet.co.za/assets/pdf/Lombaard 93 GOW1.pdf

--- 2012/2014. Un/modern post-secularism: Now you see God ... now you don't! - The non/absence of God as characteristic of post-secular faith in the modern world, in some Wisdom Writings of the Hebrew Bible and in some key moments from Christian spirituality history. Paper presented on 31 October 2012 at the Faculty of Theology, Åbo Akademi University, Turku, Finland. Publication forthcoming: Acta Theologica, 2014.

--- 2011a. No empire, no Bible? Aspects of the relationship between biblical texts and current anti-empire views. Studia Historiae Ecclesiasticae XXXVII, 49-65.

--- 2011b. The mystifying mosaic of Moses: On Pentateuch theory and Biblical spirituality (Invited guest lecture, St. Edward's University, Austin, Texas, USA, 14 October 2010, via Skype). HTS Theological Studies 67/3, Art. \#1121 (http:/l dx.doi.org/10.4102/hts.v67i3.112).

--- 2009. Why the fuss over Brown's The Da Vinci code? The dynamism of "icons" and the in/stability of meaning. Koers - Bulletin for Christian Scholarship 74/1\&2, 285-298 (= 10.4102/koers.v74i1\&2.127)

--- 2008a. Betwixt text and nature, God and evolution. Biblical reception and creationism at the Creation Museum in cultural-anthropological perspective. Tydskrif vir Semitistiek / Journal for Semitics 19/1, 263-283.

--- 2008b. What is Biblical Spirituality? - Perspectives from a minor genre of Old Testament scholarship, in: Blommestijn, H, Caspers, C, Hofman, R, Mertens, F, Nissen, P \& Welzen, H (eds.) 2008. Seeing the seeker. Explorations in the discipline of Spirituality (Festschrift for Kees Waaijman; Studies in Spirituality Supplement 19). Louvain, Belgium: Peeters, 139-153. 
LOMBAARD, CJS

--- 2008c. Problems of narratological analyses of Genesis 22:1-19, in Augustin, M \& Niemann, HM (eds) 2008. Thinking towards new horizons. Collected communications to the XIXth congress of the International Organization for the Study of the Old Testament, Ljubljana 2007 (Beiträge zur Erforschung des Alten Testaments und des Antiken Judentums 55). Bern: Peter Lang, 49-62.

--- 2006. Religieuse Kommunikasie: ter omskrywing van 'n ontluikende akademiese dissipline. Tydskrif vir Christelike Wetenskap / Journal for Christian Scholarship 42/3, 141-150.

Lombaard, C \& Froneman, J 2006. Three broad approaches to the study of religious communication. Tydskrif vir Christelike Wetenskap / Journal for Christian Scholarship 42/3, 151-158.

--- 2002. Elke vertaling is 'n vertelling. Opmerkings oor vertaalteorie, geillustreer aan die hand van die chokmatiese ratio interpretationis. Old Testament Essays 15/3, 754-765.

Louw, J P 1973. Discourse analysis and the Greek New Testament. The Bible Translator 24/1,108-118.

Lyotard, J-F 1979. La condition postmoderne: rapport sur le savoir. Paris: Minuit.

Mugridge, C A \& Gannon, M 2008. John Paul II, development of a theology of communication: excellence in the communication of the faith as exemplified in the Apostolic Exhortation, Ecclesia in America. Vatican City: Libreria Editrice Vaticana.

Narula, U 2006. Handbook of Communication. Models, perspectives, strategies. New Delhi: Atlantic Publishers.

Nynäs, P, Lassander, M \& Utriainen, T (eds.) 2012. Post-Secular Society. New Brunswick, New Jersey: Transaction Publishers.

Ochs, P \& Levene, N 2002. Textual reasonings. Jewish philosophy and text study at the end of the twentieth century. London: SCM Press. 
Otto, E 2004. The Pentateuch in synchronical and diachronical perspectives: protorabbinic scribal erudition mediating between Deuteronomy and Priestly Code, in: Otto, E \& Achenbach, R (Hrsg.) Das Deuteronomium zwischen Pentateuch und Deuteronomistischem Geschichtswerk. Göttingen: Vandenhoeck \& Ruprecht, 14-35.

Page, H R 2012. Engaging sacred text in an era of globalization: toward a new hermeneutical paradig, in Morgan, JH (ed.) The Runcie lectures 2000-2012. Mishawaka, Indiana: Graduate Theological Foundation, 137-154.

Patte, D 1990. The religious dimensions of biblical texts: Greima's structural semiotics and biblical exegesis. Atlanta: Society of Biblical Literature.

Perrin, N 1969. What is Redaction Criticism? Philadelphia: Fortress Press.

Petzer, K 1990. Die Teks van die Nuwe Testament. 'n Inleiding in die basiese aspekte van die teorie en praktyk van die tekskritiek van die Nuwe Testament (Supplementum 2 tot Hervormde Teologiese Studies). Pretoria: Tydskrifafdeling, Nederduitsch Hervormde Kerk van Afrika.

Porter, S E \& Clarke, K D 1997. What is exegesis? An analysis of various definitions, in Porter, SE (ed.) Handbook to exegesis of the New Testiment. Leiden, Brill, 4-21.

Prinsloo, W S 1988. Van kateder tot kansel. 'n Eksegetiese verkenning van enkele Psalms (tweede uitgawe). Pretoria: NG Kerkboekhandel.

Regan, D 1993. A 'new' pastoral practice: mystagogy. The Furrow 44/7\&8, 416-422.

Reilly, H M 1974. Christian initiation. Washington, DC: The Catholic University of American Consortium Press.

Richardson, K A 2007. The Antiochene school, in Porter, SE (ed.) Dictionary of biblical criticism and interpretation. Abingdon: Routledge, 14-16.

Richter, W 1971. Exegese als Literaturwissenschaft. Entwurf einer alttestamentliche Literaturtheorie und Methodologie. Göttingen: Vandenhoeck \& Ruprecht.

Sæbø, M (ed.) 1996. Hebrew Bible, Old Testament. The history of its interpretation. Göttingen: Vandenhoeck \& Ruprecht. 
Segami, T M 2008. African sprituality set in a context of Batswana Christians (MTh dissertation). Pretoria: University of South Africa

Segovia, F F 2003. Toward a new heaven and a new earth. Essays in honor of Elisabeth Schüssler Fiorenza. Maryknoll: Orbis Books.

Schultze, Q J 2000. Communicating for life. Christian stewardship in community and media. Grand Rapids: Baker Academic.

Soulen, R N \& Soulen, R K 2001. Handbook of biblical criticism (third edition). Louisville: Westminster John Knox Press.

Tolmie, D F 1999. Narratology and biblical narratives: a practical guide. San Francisco: International Scholars Publications.

Van der Merwe, D G 2012. Spiritual discernment according to 1 Corinthians 2: the Spirit and discerning the wisdom of God (An exploration in Pauline discernment: Part 1). Ned. Geref. Teologiese Tydskrif 53/3, 168-185.

--- 1995. Discipleship in the fourth gospel (DD thesis). Pretoria: University of Pretoria.

Vanhoozer, K J 1998. Is there a meaning in this text? The Bible, the reader, and the morality of literary knowledge. Grand Rapids: Zondervan.

Vojtíšek, Z, Ostřanský, B, Lukeš, J \& Biernot, D (eds) 2013. Millenialism. Prague: Dingir.

Von Rad, G 1960. Theologie des Alten Testaments. München: Chr. Kaiser Verlag.

Waaijman, K 2011. Biblical Spirituality: an "other” reading (allègoria), in: De Villiers, P \& Pietersen, L (eds). The Spirit that inspires. Perspectives on Biblical Spirituality (Acta Theologica Supplementum 15). Bloemfontein: University of the Free State Press, 1-20.

--- 2002. Spirituality: forms, foundations, methods. Dudley, Massachusetts: Peeters.

Webster, J B 2008. Biblical Reasoning. Anglican Theological Review 90, 733-751.

Wellhausen, J 1876. Die Composition des Hexateuchs und der historischen Bücher des Alten Testaments. Berlin: G. Reimer. 
Zuck, R B 1984. Basic Bible interpretation. Colorado Springs: David C. Cook.

\section{KEY WORDS}

Exegetical method

Religious Communication

Holy Texts

Extraction of meaning

Communicative intent

\section{TREFWOORDE}

Eksegetiese metodiek

Religieuse kommunikasiekunde

Heilige tekste

Verhaling van betekenis

Kommunikatiewe bedoeling 
